\title{
THE NEW DOCUMENT ABOUT THE BULAVIN UPRISING (1708) ${ }^{1}$
}

\author{
Pyotr A. Avakov \\ Federal Research Centre The Southern Scientific Centre of the Russian Academy of Sciences, \\ Rostov-on-Don, Russian Federation
}

\begin{abstract}
Introduction. A new source on the history of the Bulavin Uprising of 1707-1709 is published: a report of the Azov Governor I.A. Tolstoy to the Ambassadorial Chancery of December 8, 1708, which is stored in the Russian State Archive of Ancient Acts. It was sent in response to a request for an order about the Gulyashiy Chelovek (Freeman Wanderer) Grigory Zaitsev, nicknamed Banshick (Bath Attendant), accused of aiding Kondraty Bulavin. Analysis. Despite the brevity of the presentation, the document is very informative. It contains information about the events that took place in Cherkassk and Azov in June 1708. New details are reported about the organization of the rebel-led campaign against Azov, about Ataman K.A. Bulavin's hopes for support from the Azov residents and soldiers, about the conspiracy against him in Cherkassk, etc. No less important is the data on how the preliminary investigation of state crimes (participation in a rebellion) was conducted at the Ambassadorial Chancery in the second half of 1708. On the example of the G.K. Zaitsev's case we see that the investigation, which started because of a denunciation, was carried out in accordance with the norms of procedural law adopted at that time and was accompanied by the collection of evidence. At the same time, the paper is a source of biographical information about the person under investigation, who unwittingly became an agent of the Cherkassk's conspirators and an informant of the Azov governor. Methods. The publication is prepared in accordance with the applicable rules of archaeography. Results. The published document allows us to verify some other sources introduced into scientific circulation earlier, and extends the knowledge available in science about the culmination of the Bulavin Uprising.

Key words: Bulavin Uprising, Don Cossacks, Azov, popular movements, investigative legal proceedings, clerical sources.
\end{abstract}

Citation. Avakov P.A. The New Document About the Bulavin Uprising (1708). Vestnik Volgogradskogo gosudarstvennogo universiteta. Seriya 4. Istoriya. Regionovedenie. Mezhdunarodnye otnosheniya [Science Journal of Volgograd State University. History. Area Studies. International Relations], 2021, vol. 26, no. 4, pp. 79-88. (in Russian). DOI: https://doi.org/10.15688/jvolsu4.2021.4.7

УДК 94(47).05(093)“1707-1709”

ББК 63.3(2)511-4
Дата поступления статьи: 05.05.2020

Дата принятия статьи: 11.06.2020

\section{НОВЫЙ ДОКУМЕНТ О БУЛАВИНСКОМ ВОССТАНИИ (1708 г.) ${ }^{1}$}

\author{
Петр Ашотович Аваков \\ Федеральный исследовательский центр Южный научный центр РАН, \\ г. Ростов-на-Дону, Российская Федерация
}

\begin{abstract}
Аннотация. Публикуется новый источник по истории Булавинского восстания 1707-1709 гг.: отписка азовского губернатора И.А. Толстого в Посольский приказ от 8 декабря 1708 г., хранящаяся в Российском государственном архиве древних актов. Она была отправлена в ответ на запрос приказа о гулящем человеке حิ Григории Зайцеве по прозвищу Банщик, обвиненном в пособничестве Кондратию Булавину. Несмотря на л лаконичность изложения, документ весьма информативен. Он содержит сведения о событиях, происходивших в Черкасске и в Азове в июне 1708 года. Сообщаются новые подробности об организации повстанцами похода к Азову, о надежде атамана К.А. Булавина на поддержку азовских жителей и солдат, о заговоре против него в Черкасске, и т. д. Не менее важны данные о том, как в Посольском приказе во второй половине 1708 г. велось предварительное следствие по делам о государственных преступлениях (участие в бунте). На примере () дела Г.К. Зайцева мы видим, что начатый по извету розыск производился в соответствии с принятыми в то
\end{abstract}


время нормами процессуального права и сопровождался сбором доказательств. Одновременно отписка является источником биографических данных о подследственном, невольно ставшим агентом черкасских заговорщиков и осведомителем азовского губернатора. Публикация подготовлена в соответствии с действующими правилами археографии. Публикуемый документ позволяет верифицировать некоторые другие источники, введенные в научный оборот ранее, и расширяет имеющиеся в науке знания о кульминационном этапе Булавинского восстания.

Ключевые слова: Булавинское восстание, донское казачество, Азов, народные движения, розыскное судопроизводство, делопроизводственные источники.

Цитирование. Аваков П. А. Новый документ о Булавинском восстании (1708 г.) // Вестник Волгоградского государственного университета. Серия 4, История. Регионоведение. Международные отношения. 2021. - T. 26, № 4. - C. 79-88. - DOI: https://doi.org/10.15688/jvolsu4.2021.4.7

Введение. В конце 1950-х гг. у советских историков были все основания утверждать, что поднятое К.А. Булавиным восстание является «наименее изученным звеном в цепи крестьянских войн XVII-XVIII столетий» - даже в условиях, когда «Октябрьская революция открыла широкие возможности для изучения истории народных масс и народных волнений» [8, с. 152; цит.: 12, с. 119. Ср.: 22, с. 23]. Между тем введенный к тому времени в научный оборот документальный материал вполне благоприятствовал успешной разработке этой проблемы. По меткому замечанию Е.П. Подъяпольской, в сборнике 1935 г. [6] «было опубликовано неизмеримо больше документов из истории Булавинского восстания, чем за предшествовавшие два с четвертью века» [12, с. 119]. Разумеется, издание включало в себя далеко не все доступные исследователям архивные материалы по истории восстания, публикация которых была продолжена в последующие годы В.И. Лебедевым, Е.П. Подъяпольской и некоторыми другими авторами, в том числе в рамках продолжающегося издания «Письма и бумаги императора Петра Великого» [11-14; 17-21].

Перелом в историографической ситуации наступил после выхода в свет монографии самой Е.П. Подъяпольской [20]. Книга имела положительный резонанс и словно послужила толчком для дальнейшего исследования темы. Тем не менее некоторые вопросы и противоречия, возникшие в процессе изучения советскими историками Булавинского восстания, остаются нерешенными до сих пор. Появление многих из них было обусловлено марксистской методологией, господствовавшей в советской исторической науке: порожденный формационно-классовой теорией концепт крес- тьянских войн стал своеобразным прокрустовым ложем для этого специфического антиправительственного движения [10, с. 27-28]. К таковым спорным моментам в первую очередь относятся взаимосвязанные проблемы определения хронологических рамок восстания и его характера.

Если поначалу историки датировали движение К.А. Булавина 1707-1708 гг., то Е.П. Подъяпольская в качестве верхней даты указала 1709 г., а А.П. Пронштейн и Н.А. Мининков и вовсе отодвинули ее к 1710 г. [22, с. 119-198; 24, с. 203288]. По этому поводу В.И. Буганов и А.П. Новосельцев не без резона возразили, что «называть восстание, в которое в 1709-1710 гг. включились огромные массы крестьян южнорусских уездов, Булавинским, вряд ли верно», особенно учитывая факт гибели самого атамана в июле 1708 г. [5, с. 125]. Произошедшую в советской историографии 50-70-х гг. ХХ в. эволюцию характеристики движения К.А. Булавина можно проследить по работам Е.П. Подъяпольской. Если в 1962 г. она еще характеризовала его как «крестьянско-казацкое восстание», то в 1979 г. уже безоговорочно квалифицировала как крестьянскую войну [22, с. 197; 23]. Следуя историографическому тренду, исследовательница в каком-то смысле пошла на поводу у его приверженцев, рецензировавших ее монографию - В.И. Буганова и В.И. Лебедева. Последние раскритиковали определение, которое она дала движению, и предложили именовать его «крестьянской войной начала XVIII в.», не фокусируя внимание на личности К.А. Булавина, поскольку восстание «довольно долго продолжалось и после его гибели», когда «выделились другие его руководители» [4, с. 125-126]. И хотя после выхода в 1986 г. ревизионистской статьи Н.И. Павлен- 
ко с характером и главной движущей силой восстания многое прояснилось - ученый обоснованно считал его «казачьим по преимуществу» [16, с. 68-74], ряд вопросов все еще требуют уточнения.

После освобождения отечественной науки от идеологического диктата «марксизма-ленинизма» на исходе XX в. интерес историков к массовым народным движениям в России «эпохи феодализма» заметно снизился, следствием чего стало резкое сокращение исследований по этой проблематике, особенно монографических. Давно и в немалом количестве опубликованные источники о Булавинском восстании все еще ждут нового теоретического осмысления вне марксистской парадигмы. О массовом же введении в научный оборот новых архивных материалов по его истории говорить пока не приходится. Количество документов об этом народном движении, опубликованных в последние два десятилетия, измеряется буквально единицами, причем некоторые из них либо уже были известны историкам, либо публиковались ранее [2;9].

Публикуемая ниже отписка азовского губернатора, стольника Ивана Андреевича Толстого в Посольский приказ от 8 декабря 1708 г., отложившаяся в фонде «Приказные дела новой разборки» (№ 159) Российского государственного архива древних актов, еще не была введена в научный оборот $[15$, л. $1-$ 2 об.]. Для изучения истории Булавинского восстания она представляет немалый интерес по целому ряду оснований.

Анализ. Прежде всего, отписка сообщает дополнительные подробности о событиях, происходивших в Черкасске и Азове в июне 1708 г., накануне неудачного похода булавинцев к Азову. Это сведения об организации похода (численность участников которого определяется в 4000 человек, что совпадает со свидетельством донского казака Евсевия Мельникова [1, с. 188]), о надежде К.А. Булавина на поддержку со стороны азовской «черни» и гарнизонных солдат, о заговоре против него, о сотрудничестве заговорщиков с азовским губернатором, о верификации им получаемых из Черкасска агентурных данных, и т. д. Не менее важна содержащаяся в документе информация другого уровня - о том, как в Посольском приказе во второй половине 1708 г. велось предварительное следствие над теми, кто подозревался в пособничестве К.А. Булавину. На примере дела гулящего человека Григория Кирилловича Зайцева (Банщика) мы видим, что начатый по извету розыск производился в соответствии с принятыми в то время нормами процессуального права и в том числе сопровождался сбором доказательств [3, с. 112, 113]. Ответом на запрос приказа и стала публикуемая отписка, составленная на основе документов текущего архива азовской приказной палаты и подтверждающая показания Г.К. Зайцева. Исход следствия, продолжившегося уже в Преображенском приказе, нам неизвестен, но полученные от И.А. Толстого сведения позволяют предположить, что обвиняемый был оправдан. Таким образом, отписка одновременно является источником биографических данных о подследственном, невольно ставшим агентом черкасских заговорщиков и осведомителем азовской администрации.

Для внесения ясности в предысторию появления публикуемого документа перескажем суть упомянутого розыскного дела по его черновику, составленному в Посольском приказе в сентябре 1708 года.

8 сентября 1708 г. находившийся в Москве казак «легкой» донской станицы Василий Болдырь, случайно встретив в месте розничной продажи алкогольных напитков незнакомца, узнал в нем ранее виденного им сообщника К.А. Булавина. Вернее, он подозревал его в причастности к восстанию из-за шапки, которую тот носил в Черкасске - ранее она якобы принадлежала бывшему войсковому есаулу Кирею Семенову, «которого воры Булавин с товарыщи в воду посадили» (то есть казнили утоплением). В. Болдырь сообщил об этом возглавлявшему станицу атаману Василию Лаврентьевичу Большому Позднееву, по приказу которого незнакомец был незамедлительно арестован станичным есаулом Иваном Селивановым с казаками и приведен к ним на двор. Атаман опознал его как «гулящего человека, родом черкашенина» (то есть украинца) Григория по прозвищу Банник, или Банщик ${ }^{2}$, проживавшего на Дону во время Азовских походов 1695-1696 гг. и затем работавшего банщиком в торговых банях в Троицком 
на Таган-роге. Карьера банщика не задалась: «зоворовав», он якобы продал те бани без ведома их хозяев и сбежал с деньгами, после чего служил солдатом в Санкт-Петербурге, а во время Булавинского восстания опять появился на Дону, и даже дважды приходил к В.Л. Позднееву (и другим знатным старшинам) на двор, но тот «ево к себе не пускал и в слова с ним ни в какие не вступал, опасая себя», поскольку считал, что он подослан К.А. Булавиным «выведывать намерения их». Однако во время допроса станичным атаманом Григорий отвел все выдвинутые против него обвинения. Он заявил, что «...от салдатцкой службы отставлен, и сшел в Троецкое, и был на взморье в рыбных ловцах, а потом в Черкаской пришел... по отпуску из Азова воеводы Степана Киреева для присматривания всяких поведений, которые происходили от бунтовщиков Булавина с товарыщи, и про тое де ево из Азова присылку ведает донской казак Василий Фролов». В Москву же бывший банщик, а ныне рыболов приехал с шестью «рыбными промышленниками, рускими людьми». На вопрос о том, где он взял свою шапку, Григорий трижды ответил по-разному: сначала, «что тое шапку взял он на Дону в Черкаском на кабаке на бочке, а вдругоредь сказал, что купил, а в третие сказал, что на кругу взял по приказу казаков». После дознания казаки доставили подозреваемого в Посольский приказ «для подлинного о нем розыску» [7, л. 1-2].

На следующий день, 9 сентября, Григорий был допрошен в Ближней канцелярии «государевыми боярами» - членами правительственной комиссии, осуществлявшей текущее руководство страной в отсутствие царя, находившегося в действующей армии. На этот раз подследственный рассказал о себе больше и объяснил противоречия в своих прежних показаниях. Зовут его Григорий Кириллов сын Банщик, родился он в Киеве, куда в прошлом был переведен из Касимова его отец - служилый человек «руской породы», зачисленный в стрелецкий полк киевского гарнизона. С местом рождения связано второе прозвище Григория - Киевенец (то есть киевлянин). Оставшись после смерти отца в «малых летех» круглым сиротой, он жил у «купецких людей», a с наступлением 17-летнего возраста женился на вдове грека Михаила в доме мещанина
Мартына Сыча. Два года спустя, около 1692 г., когда в Киев на богомолье приехал донской войсковой атаман Фрол Минаев, Григорий с женой переехал жить в Черкасск. Поселившись у атамана, он шесть лет «торговал от него медом вареным», а после взятия российскими войсками Азова в 1696 г. перебрался туда. В Азове он держал «торговые бани» одну «государеву» на откупе, а вторую свою, на паях с донским казаком Петром Греком (более известным как Петр Емельянович Рамазан). Кроме того, около года он владел еще одной баней в Троицком совместно с Яном Греком (азовским полковником Венедиктом Семеновичем Яном), которому затем продал свою «половину» за 60 рублей. Уступив долю азовской бани своему партнеру П.Е. Рамазану в качестве уплаты долга, Григорий уехал «для торгового промысла» в Новгород с приезжими купцами из Белёва, которые продавали в Азове мед и продукты питания. Поторговав в Новгороде около четырех месяцев, компаньоны отправились для этого же в Санкт-Петербург, откуда через полгода разъехались по домам: белёвцы - в Белёв, а Григорий - в Черкасск, где его ждала жена, вернувшаяся туда на жительство из Азова. Исходя из того, что с тех пор «минуло лет с пять», купцы торговали в Петербурге в 1703 г. - в первый год существования будущей российской столицы. Причем находясь там, Григорий в солдатах «не бывал» и нигде не служил. Пожив недолго в Черкасске, он переселился в Павловский шанец у устья р. Миус, где около пяти лет занимался рыболовным промыслом, работая на посадского человека Терентия Бурлака. Наконец, спустя четыре недели после казни булавинцами прежнего войскового атамана Лукьяна Максимова и близких к нему старшин, «как те бунты утишились» (то есть в начале июня 1708 г.), Григорий вместе с казаком Павловской станицы Черкасска Власом Ивановым приехал в войсковою столицу для продажи морской рыбы. Побыв в Черкасске две недели, он сбежал на лодке в Азов, когда К.А. Булавин начал сбор казаков для нападения на этот город (согласно публикуемому документу, это произошло 18 июня). Перед бегством он получил от старшин Ильи Григорьева (Зернщикова) и Федора Соколовского поручение предупредить воеводу Сте- 
пана Васильевича Киреева (заместителя находившегося в Троицком губернатора) о подготовке булавинцами похода на Азов. Говоря о И.Г. Зернщикове и Ф. Соколовском, Григорий пояснил, что «ныне» они войсковой атаман и войсковой дьяк - это отражало ситуацию на Дону во время его отъезда в Москву после гибели К.А. Булавина и разгрома его сторонников в Черкасске. Прибыв в Азов, Григорий сообщил обо всем стольнику С.В. Кирееву. Воевода ему не поверил и посадил его под арест, но через четыре дня, после поражения булавинцев под Азовом 6 июля, освободил, пообещав за оказанную услугу «великого государя милость». Из Азова Григорий добрался морем на бударе до Таганрога, а оттуда - домой в Павловский шанец. Примерно шесть недель назад, то есть в конце июля, он решил присоединиться к троицким посадским людям Андрею и Максиму Яковлевым, отправлявшимся в Москву торговать рыбой, и «поехал с ними в работниках из найму». На этот счет у его нанимателей имелось прямое доказательство - выданная в Троицком подорожная «об отпуске их и о пропуске по дороге». По прибытии в столицу они остановились на постоялом дворе в Верхних Садовниках, близ каменного моста (Всехсвятского, соединявшего Замоскворечье с Белым городом), где Григория и задержали донские казаки [7, л. 2-4].

По поводу своей шапки, которая служила главным аргументом для его обвинения в причастности к Булавинскому восстанию, Григорий пояснил, что купил ее «в кругу у казака Василия», когда «ездил с Таган-рогу в Черкаской с продажною рыбою». Тогда же из-за той шапки незнакомый казак, одетый в покрытую зеленым киндяком шубу, схватил его и обвинил в воровстве. Это послужило основанием для разбирательства в Войсковом круге, в результате чего Григорий был оправдан, а обвинителю «в той шапке отказано». Подследственный подчеркнул, что своего недоброжелателя знает только в лицо, «а как зовут и чей прозваньем - не знает», «но чает, что он ныне в приезде в Москве, потому что в такой же шубе видел казака», который сказал ему: «ты де вор, много де от тебя мы потерпели» (возможно, речь идет о В. Болдыре, узнавшем его на постоялом дворе в Верхних
Садовниках). Во время же допроса В.Л. Позднеевым Григорий говорил ему о другой своей шапке, а не о купленной, «потому что он пил в кабаке, и тое свою шапку забыл, а на другой день с кабака с бочки взял». По поводу обвинения в причастности к восстанию допрашиваемый заявил, что с булавинцами «в воровствах их и согласии» он не был, при утоплении есаула К. Семенова не присутствовал, «и той шапки, про которую казаки говорят, не имовал». То, «что он человек доброй, а не вор», могут подтвердить представители войсковых властей - И.Г. Зернщиков и Ф. Соколовский, и троицкие посадские люди. Что касается его слов об отставке с солдатской службы в Петербурге, сказанных днем ранее Л.В. Позднееву, - он «того не упомнит, потому что был пьян» [7, л. 2 об., 4-4 об.]. В данной ситуации эта традиционная отговорка всех находящихся в тисках правосудия лиц звучала вполне правдоподобно, учитывая, что Григорий был задержан казаками после распития алкогольных напитков.

Нельзя не обратить внимания на то, что в материалах розыскного дела и публикуемом документе имеются некоторые расхождения. Прежде всего, это касается двоякого социального статуса фигуранта. Согласно показаниям Г.К. Зайцева в Посольском приказе, он принадлежал к категории гулящих людей, о чем ясно свидетельствует его образ жизни и род деятельности. Тем не менее И.А. Толстой назвал Григория донским казаком Павловской станицы Черкасска - вероятно, исходя из его предыдущего места пребывания [15, л. 1 об.]. С другой стороны, проживание подследственного в Черкасске до 1695 г. (рубежная дата для социальной сегрегации пришлого и старожилого населения донских городков с точки зрения закона) давало и юридические основания считать его казаком. Правда, судя по роду деятельности последнего на Дону и его свободе передвижения, он не нес казачьей службы и, следовательно, казаком не являлся.

В отписке И.А. Толстого, передающей слова Г.К. Зайцева, среди пославших его в Азов членов антибулавинского заговора фигурирует В.Л. Большой Позднеев [15, л. 1 об.], однако материалы дела недвусмысленно свидетельствуют, что они не были знакомы - 
иначе бы старшина узнал своего агента (в том, что отправившуюся в августе 1708 г. из Черкасска в Москву «легкую» станицу возглавлял именно Василий Позднеев-старший, а не его родной младший брат-тезка, сомневаться не приходится [19, с. 468, 588-590]). Вместе с тем большого противоречия в этом нет. То, что на допросе в Азове в июне 1708 г. Григорий назвал трех черкасских заговорщиков, от имени которых он передал С.В. Кирееву сведения о планах К.А. Булавина, вовсе не означает, что все они лично уполномочили его на это. Иными словами, В.Л. Позднеев мог не присутствовать при инструктировании двумя своими сообщниками Г.К. Зайцева, и поэтому не узнал его в Москве почти три месяца спустя.

Методы. Документ публикуется в соответствии с «Правилами издания исторических документов в СССР» (М., 1990). Его орфографические и стилистические особенности сохранены, вышедшие из употребления буквы русского языка заменены на созвучные им современные буквы, а кириллическая цифирь - на арабские цифры. Выносные буквы внесены в строку, сокращения слов раскрыты, твердый знак в конце слов не воспроизводится. Мягкий знак и знаки препинания расставлены в соответствии с действующими правилами орфографии и пунктуации. Границы листов документа обозначены двумя вертикальными линиями: $\|$.

\section{Отписка губернатора Азова стольника И.А. Толстого в Посольский приказ}

8 декабря 1708 г.

(Л. 1 об.) Великому государю, царю и великому князю Петру Алексеевичю ${ }^{(1)}$, всеа Великия, и Малыя и Белыя Росии самодержцу, холопи твои, Иван Толстой ${ }^{(2)}$ с товарыщи, челом бьют.

В нынешнем 708-м году октября в 30 день в твоих, великого государя, царя и великого князя Петра Алексеевича всеа Великия, и Малыя и Белыя Росии самодержца, дву грамотах из государственного Посольского приказу в Азов, к нам, холопем твоим, за приписью секретора Петра Курбатова ${ }^{(3)}$ писано, велено против роспросных речей Григорья Банщикова, которой ис Троицкого ${ }^{(4)}$ приехал к Москве с торговыми людьми с Андреем Авериным, да с Максимом Поповым в работниках, а во время бунту вора Булавина ${ }^{(5)}$ был он на Дону, освидетельствовав, к тебе, великому государю, писать чрез почту наскоро: в бунту вора Булавина он, Григорей Банщиков, $з$ Дону ис Черкаскаго ${ }^{(6)}$ от старшин Ильи Григорьева ${ }^{(7)}$ с товарыщи с ведомостию о зборе и о приходе под Азов ${ }^{(8)}$ булавинцов присылан ли, и что он о том в Азове объявил, и в Троицком на Таган-рогу, и в Павловском ${ }^{(9)}$ у кого он жил, и не было ль за ним какова воровства.

И по тем де твоим, великого государя, грамотам, по справке в азовской приказной полате в нынешнем 1708-м году июня в 27 день явился в Азове Черкаскаго городка Павловской станицы ${ }^{(\mathbf{1 0})}$ казак Григорей Кирилов сын Зайцов, и в приказной полате перед нами, холопи твоим, сказал: июня де в 18-м числе донские казаки есаул Тимофей Соколов ${ }^{(11)}$ да Илья Григорьев, Василей Большой Познеев ${ }^{(12)}$, Михайла Сулин ${ }^{(13)}$, Иван Юдушкин ${ }^{(14)}$, послали ево, Григорья, ис Черкаскаго в Азов с письмом, в котором было написано про воровство вора Булавина, что он в Черкаском. || (Л. 2) И как де он, Григорей, ис Черкаскаго в Азов с тем поехал рекою Доном в лотке, и в урочище де против Лычанского острова $^{(15)}$, и с того острова осмотря ево, лютинские казаки ${ }^{\mathbf{( 1 6 )}}$, окликав, взяли для отвозу в Черкаской. А как ево брали, и в то время посланное с ним, Григорьем, письмо, кинул он в реку Дон, чтоб то письмо у него не вынели. И привезли де ево в Черкаской, и вор де Булавин в кругу ево роспрашивал. И он де, Григорей, про ту посылку ему, вору, не сказал, а сказал, что ехал на рыбную ловлю. И посля де роспросу он, вор, посадил ево на цепь, и на цепе де сидел он неделю, и с той де цепи по упрошению есоулов Тимофея Соколова и Степана Ананьина ${ }^{(17)}$ он, вор, ево, Григорья, с цепи свободил. И июня ж де в 26 день вышеписанные есоул Тимофей Соколов да есаул же Степан Ананьин, Василей Большой Познеев, призвав ево, Григорья, и велел ему итить тайным обычаем в Азов, и явитца в Азове нам, холопем твоим. А при отпуске де ево ис Черкаскаго вышеписанные есаул Тимофей Соколов с товарыщи приказывали с ним, Григорьем, нам, холопем твоим, сказать, чтоб в Азове и в Троицком имели опосение для того, что де вор Булавин имеет свое воровское намерение итить войною под Азов, и казаки де все верстались в десятки. А по смете де казаков и бурлаков и бокчевников ${ }^{(18)} \mathrm{c}$ четыря тысичи человек. А к Азову де он, вор, пойдет судовою сам, а конницею по Крымской сторане ${ }^{(19)}$ пойдут воры Беспалой (20) да Лунька Хохлач ${ }^{(21)}$ с товарыщи. И для того де он, вор, Беспалаго ожидает к себе вскоре. Да он же, Григорей, втайне сказал: вор де Булавин в кругу и везде говорит, чтоб итить под Азов войною. А как де он под Азов придет, и салдаты де и чернь вся нигде с ним битца не будут, и в том де $\|$ (Л. 2 об.) он на них, салдат и чернь, крепко надеетца, развя де с ним будут битца начальные люди да дворяня, да иноземцы, да по- 
садцкие люди. И Тимофей де Соколов с товарыщи приказывал с ним, Григорьем, чтоб салдат и иных чинов черных людей не роздрожать, а обещал бы им великого государя милость и жалованья, и во всем бы их, салдат, и иных чинов людей, уверил подлинно - для того, что де он, вор, хочет чернь всю прельщать. И для подлиннаго о вышеписанном уверения отдан был за кораул. А как воры булавинцы под Азов приходили, и по окончании оного воровства июля в 9 день он, Григорей, из-за короулу свобожен, и из Азова съехал в Троицкой.

А наперед сего он, Григорей, в Азове и в Троицком живал и торговые бани, взяв, на откупу держал, а какова он состояния и шатость какая за ним была ль - того в Азове и в Троицком неведомо. А в приводех ни в каких в приказные полаты не бывал.

А сию отписку к тебе, великому государю, царю и великому князю Петру Алексеевичю, всеа Великия, и Малыя и Белыя Росии самодержцу, послали мы, холопи твои, чрез почту декабря в 8 день, и велели подать в твоем государственном Посольском приказе постельничему и каволеру графу Гаврилу Ивановичю Головкину ${ }^{(22)}$ да тайному секретару Петру Павловичю Шафирову ${ }^{(23)}$ с товарыщи.

РГАДА. Ф. 159. Оп. 2. Д. 5041. Л. 1-2 об. Подлинник

Под текстом отписки помета другим почерком (л. 2. об.):

1709-го генваря в 4 день. Послать с сей отписки для ведома в Преображенской приказ память для того, что тот донской казак, о котором в сей отписке писано, отослан из Посолского прика[за] в тот приказ.

Письмо было сложено конвертом, на его внешней стороне фрагмент круглой сургучной печати и надпись (л. 1):

В Посольской приказ.

Великому государю, царю и великому князю Петру Алексеевичю, всеа Великия, и Малыя и Белыя Росии самодержцу.

Ниже отметка тем же почерком, что $и$ помета на отписке:

1709-го генваря в 4 день прислана в Розряд чрез почту.

\section{КОММЕНТАРИИ}

1. Петр I Алексеевич (1672-1725), русский царь с 1682 года.
2. Иван Андреевич Толстой (1642-1713), стольник с 1677 г., губернатор Азова с 1703 г. и Азовской губернии в 1709-1713 годах.

3. Курбатов Петр Васильевич (1672-1747), секретарь Посольского приказа с 1708 года.

4. Город-крепость Троицкий на Таган-роге (мысе Таган), более известный в историографии как Таганрог. Основан в 1699 г., разрушен по условиям Прутского мирного договора 1711 года. Ныне на его месте находится г. Таганрог Ростовской области.

5. Булавин Кондратий Афанасьевич (ок. 16671708), повстанческий атаман и лидер казачьего восстания 1707-1708 гг., войсковой атаман Войска Донского в 1708 году.

6. Черкасский городок (Черкасск), военно-административный центр Войска Донского в 16441805 годах. Ныне - станица Старочеркасская в Аксайском районе Ростовской области.

7. Зер(н)щиков Илья Григорьевич (ум. 1708), старшина Войска Донского, войсковой атаман в 1708 году.

8. Город Азов, административный центр Северо-Восточного Приазовья, бывшая османская крепость Азак. Завоеван и включен в состав России в 1696 г., возвращен Османской империи по условиям Прутского мирного договора 1711 года. Ныне г. Азов в Азовском районе Ростовской области.

9. Павловский шанец - земляное укрепление в устье р. Миус, на западном фланге оборонительной Троицкой линии. Построен в 1702 г., оставлен в 1711 году.

10. Павловская - одна из одиннадцати станиц в составе г. Черкасска.

11. Соколов Тимофей (Гаврилович?), донской казак Средней станицы г. Черкасска, войсковой есаул в 1708 году.

12. Позд(н)еев Василий Большой (то есть старший) Лаврентьевич, старшина Войска Донского.

13. Сулин Михаил Филиппович, донской казак г. Черкасска, войсковой толмач в 1708 году.

14. Юдин (Юдушкин, Юдак) Иван Андреевич, донской казак г. Черкасска.

15. Лычанский остров - речной русловой остров, находившийся выше стрелки р. Дон и его протока Мертвый Донец, в черте нынешнего г. Ростова-на-Дону. В наши дни затоплен.

16. Донские казаки, поселенные в 1696 г. в бывшей османской крепости Лютин (Сед-Ислам) после ее капитуляции. Крепость располагалась в дельте р. Дон, на левом берегу р. Мертвый Донц.

17. Ананьин Степан, донской казак Верхней Рыковской станицы г. Черкасска, войсковой есаул в 1708 году. Один из убийц К.А. Булавина.

18. Бурлаки и бахчевники, здесь - пришлые жители донских станиц, не имевшие статуса казака наемные работники. 

p. Дон

19. Крымская сторона, здесь - правый берег

20. Беспалый Сергей (Федорович?), донской казак, повстанческий атаман, сподвижник К.А. Булавина.

21. Хохлач Лукьян Михайлович (ум. 1708), повстанческий атаман, сподвижник К.А. Булавина.

22. Головкин Гавриил Иванович (1660-1734) постельничий и верховный комнатный с 1689 г., судья Мастерской палаты в 1689-1712 годах. С 1706 г. глава Посольской канцелярии, с 1708 г. - Посольского и подчиненных ему приказов. Кавалер ордена Святого Андрея Первозванного с 1703 г., граф Священной Римской империи германской нации с 1707 года. Троюродный дядя царя Петра I (по материнской линии).

23. Шафиров Петр Павлович (1669-1739), тайный секретарь Посольского приказа с 1703 года.

\section{ПРИМЕЧАНИЯ}

${ }^{1}$ Статья подготовлена в рамках государственного задания ЮНЦ РАН на 2021 г. по теме «История и культура народов Юга России: между традицией и модернизацией» (№ гос. регистрации АAАAA19-119011190182-8).

The article was prepared as part of state assignments for 2021 en-trusted to the Federal Research Centre The Southern Scientific Centre of the RAS on the topic "History and Culture of the Peoples of the South of Russia: Between Tradition and Modernization" (state registration number: AAAAA19-119011190182-8).

${ }^{2}$ Его не следует путать с казаком Ново-Айдарского городка Григорием Банниковым - одним из первых сподвижников К.А. Булавина, его соучастником в убийстве князя Ю.В. Долгорукова и повстанческим полковником. Этот «бунтовщик заводчик» был пойман войсковыми властями в декабре 1707 г., вместе с тремя другими колодниками в январе 1708 г. доставлен в Посольский приказ «легкой» станицей атамана Увара Иванова и затем передан в Преображенский приказ для следственных действий $[6$, с. 131, 138, 139, 142, 151, 157].

\section{СПИСОК ЛИТЕРАТУРЫ}

1. Аваков, П. А. Азовский поход булавинцев 1708 г. / П. А. Аваков // Меншиковские чтения 2015 : науч. альманах. - СПб. : XVIII век, 2015. Вып. 6. - С. 184-194. - (Б-ка Фонда памяти светлейшего князя А.Д. Меншикова).

2. Аваков, П. А. Письмо К.А. Булавина ачуевскому мухафызу Хасану-паше (1708 г.) / П. А. Аваков,
Д. В. Сень // Вестник Волгоградского государственного университета. Серия 4, История. Регионоведение. Международные отношения. - 2018. - Т. 23, № 2. C. 62-70.-DOI: https://doi.org/10.15688/jvolsu4.2018.2.5.

3. Батиев, Л. В. Возбуждение процесса и доказывание в российском розыскном судопроизводстве второй половины XVII - начала XVIII в. / Л. В. Батиев // Гуманитарные и юридические исследования. -2019 . - № 3. - С. 110-120.

4. Буганов, В. И. Новое исследование о Булавинском восстании / В. И. Буганов, В. И. Лебедев // Вопросы истории. - 1963. - № 12. - С. 124-127.

5. Буганов, В. И. [Рец. на:] А. П. Пронштейн, Н. А. Мининков. Крестьянские войны в России XVII-XVIII веков и донское казачество. - Ростов н/ Д : Изд-во Рост. ун-та, 1983. - 420 с. / В. И. Буганов, А. П. Новосельцев // Вопросы истории. - 1984. № 12. - C. 124-127.

6. Булавинское восстание (1707-1708 гг.).- М. : Изд-во Всесоюз. о-ва политкаторжан и ссыльнопоселенцев, 1935. - 528 с. - (Тр. Историко-археографического ин-та АН СССР ; т. 12).

7. Дело по доносу станичного атамана В.Л. Позднеева-старшего на гулящего человека Г.К. Банщика. Сентябрь 1708 г. // Российский государственный архив древних актов (РГАДА). 1708 г. - Ф. 111. - Оп. 1. - Д. 9. - Л. 1-12 об.

8. Зимин, А. А. Изучение в советской исторической науке классовой борьбы периода феодализма в России (до начала XIX века) / А. А. Зимин, А. А. Преображенский // Вопросы истории. 1957. - № 12. - С. 135-160.

9. Мининков, Н. А. Первое упоминание о Кондратии Булавине / Н. А. Мининков // Новый часовой: русский военно-исторический журнал. 2002. - № 13-14. - C. 225-230.

10. Мининков, Н. А. Традиции и перспективы изучения массовых народных движений в России XVII-XVIII веков / Н. А. Мининков // Вестник Волгоградского государственного университета. Серия 4, История. Регионоведение. Международные отношения. -2019 . - Т. 24, № 2. - С. 26-35. - DOI: https://doi.org/10.15688/jvolsu4.2019.2.3.

11. Недосекин, В. И. Новые данные о Булавинском восстании / В. И. Недосекин // Советские архивы. - 1967. - № 3. - С. 107-110.

12. Новое о восстании К. Булавина / публ. Е. П. Подъяпольской // Исторический архив. 1960. - № 6. - С. 119-142.

13. Новые материалы о восстании на Дону и в Центральной России в 1707-1709 гг. / публ. Е. П. Подъяпольской // Материалы по истории СССР.-М., 1957. Вып. 5. - С. 503-564.

14. О подавлении народного восстания $1707-$ 1708 гг. / публ. В.И. Лебедева // Исторический архив. - 1955. - № 4. - С. 179-195. 
15. Отписка азовского губернатора И.А. Толстого в Посольский приказ. 8 декабря 1708 г. // РГАДА. Ф. 159. - Оп. 2. - Д. 5041. - Л. 1-2 об.

16. Павленко, Н. И. К вопросу о роли донского казачества в крестьянских войнах / Н. И. Павленко // Социально-экономическое развитие России : сб. ст. к 100-летию со дня рождения Н. М. Дружинина. - М. : Наука, 1986. - С. 62-75.

17. Письма и бумаги императора Петра Великого / ред. А. И. Андреева. - М. ; Л. : Изд-во АН СССР, 1946. - Т. 7. - Вып. 2. - VI, [639]-936 с.

18. Письма и бумаги императора Петра Великого / ред. А. И. Андреева. - М. : Изд-во АН СССР, 1948. - Т. 8. - Вып. 1. - 408 с.

19. Письма и бумаги императора Петра Великого / ред. Б. Б. Кафенгауза. - М. : Изд-во АН СССР, 1951. - Т. 8. - Вып. 2. -409-1180 с.

20. Письма и бумаги императора Петра Великого / ред. Б. Б. Кафенгауза. - М. ; Л. : Изд-во АН CCСР, 1950. - Т. 9.- Вып. 1. -528 с.

21. Письма и бумаги императора Петра Великого / ред. Б. Б. Кафенгауза. - М. : Изд-во АН СССР, 1952. - Т. 9. - Вып. 2. -529-1622 с.

22. Подъяпольская, Е. П. Восстание Булавина, 1707-1709 / Е. П. Подъяпольская. - М. : Изд-во АН СCCР, 1962.-215 c.

23. Подъяпольская, Е. П. Крестьянская война 1707-1709 гг. / Е. П. Подъяпольская // Смирнов И. И., Маньков А. Г., Подъяпольская Е. П., Мавродин В. В. Крестьянские войны в России XVII-XVIII вв. - М. ; Л. : Наука, 1966. - С. 176-203.

24. Пронштейн, А. П. Крестьянские войны в России XVII-XVIII веков и донское казачество / А. П. Пронштейн, Н. А. Мининков. - Ростов н/Д : Изд-во Рост. ун-та, 1983. - 420 с.

\section{REFERENCES}

1. Avakov P.A. Azovskij pohod bulavincev 1708 g. [The Azov Campaign of the Bulavin's Supporters of 1708]. Menshikovskie chteniya - 2015: nauch. al'manah [Menshikov Memorial Readings, 2015. The Scientific Almanac]. Saint Petersburg, XVIII vek Publ., 2015, iss. 6, pp. 184-194. (B-ka Fonda pamyati svetleyshego knyazya A.D. Menshikova [Library of the Fund for the Memory of His Serene Highness Prince A.D. Menshikov]).

2. Avakov P.A., Sen D.V. Pismo K.A. Bulavina achuyevskomu mukhafyzu Khasanu-pashe (1708 g.) [K. Bulavin's Letter to Achuev's Muhafiz Hassan Pasha (1708)]. Vestnik Volgogradskogo gosudarstvennogo universiteta. Seriya 4, Istoriya. Regionovedeniye. Mezhdunarodnyye otnosheniya [Science Journal of Volgograd State University. History. Area Studies. International Relations], 2018, vol. 23, no. 2, pp. 62-70. DOI: https://doi.org/10.15688/ jvolsu4.2018.2.5.

3. Batiev L.V. Vozbuzhdeniye protsessa i dokazyvaniye $\mathrm{v}$ rossiyskom rozysknom sudoproizvodstve vtoroy poloviny XVII - nachala XVIII v. [The Initiation of the Process and the Proof in the Russian Investigative Proceedings in the Second Half of $17^{\text {th }}$ - Beginning of $18^{\text {th }}$ Centuries]. Gumanitarnye $i$ yuridicheskie issledovaniya [Humanities and Law Studies], 2019, no. 3, pp. 110-120.

4. Buganov V.I., Lebedev V.I. Novoe issledovanie o Bulavinskom vosstanii [New Study on the Bulavin Uprising]. Voprosy istorii, 1963, no. 12, pp. 124-127.

5. Buganov V.I., Novosel'cev A.P. (Rets. na:) A.P. Pronshtejn, N.A. Mininkov. Krest'yanskie vojny v Rossii XVII-XVIII vekov i donskoe kazachestvo. Rostov n/D, Izd-voRost. un-ta, 1983.420 s. [Review: A.P. Pronstein, N.A. Mininkov. Peasant Wars in Russia of the $17^{\text {th }}-$ $18^{\text {th }}$ Centuries and the Don Cossacks. Rostov-on-Don, 1983. 420 p.]. Voprosy istorii, 1984, no. 12, pp. 124-127.

6. Bulavinskoe vosstanie (1707-1708 gg.) [The Bulavin Uprising (1707-1708)]. Moscow, Izd-vo Obshchestva byvshikh politkatorzhan i ssyl'noposelentsev, 1935. 528 p. (Tr. Istorikoarkheograficheskogo in-ta AN SSSR; t. 12 [Proceedings of the Historical and Archaeographic Institute of the Academy of Sciences of the USSR, vol. 12]).

7. Delo po donosu stanichnogo atamana V.L. Pozdneeva-starshego na gulyashchego cheloveka G.K. Banshchika. Sentyabr 1708 g. [The Case on Denunciation of the Village Ataman V.L. Pozdneev Senior on the Man from the Street G.K. Banshchik]. Rossiyskiy gosudarstvennyy arkhiv drevnikh aktov (RGADA) [The Russian State Archive of Ancient Acts (RGADA)], 1708 g., f. 111, op. 1, d. 9, 1. 1-12 ob.

8. Zimin A.A., Preobrazhenskij A.A. Izuchenie v sovetskoj istoricheskoj nauke klassovoj bor'by perioda feodalizma v Rossii (do nachala XIX veka) [The Study of the Class Struggle During Feudalism in Russia (Until the Beginning of the $19^{\text {th }}$ Century) in Soviet Historical Science]. Voprosy istorii, 1957, no. 12, pp. 135-160.

9. Mininkov N.A. Pervoe upominanie o Kondratii Bulavine [The First Mention of Kondraty Bulavin]. Novyj chasovoj: russkij voenno-istoricheskij zhurnal, 2002, no. 13-14, pp. 225-230.

10. Mininkov N.A. Tradicii i perspektivy izucheniya massovyh narodnyh dvizhenij v Rossii XVII-XVIII vekov [Traditions and Prospects of Studying Mass Public Movements in the Russia of the $17^{\text {th }}-18^{\text {th }}$ Centuries]. Vestnik Volgogradskogo gosudarstvennogo universiteta. Seriya 4, Istoriya. Regionovedenie. Mezhdunarodnye otnosheniya [Science Journal of Volgograd State University. History. Area Studies. International Relations], 2019, vol. 24, no. 2, pp. 26-35. DOI: https://doi.org/10.15688/ jvolsu4.2019.2.3. 
11. Nedosekin V.I. Novye dannye o Bulavinskom vosstanii [New Data About the Bulavin Uprising]. Sovetskie arhivy [Soviet Archives], 1967, no. 3, pp. 107-110.

12. Podjapolskaya E.P., ed. Novoe o vosstanii K. Bulavina [New About the K. Bulavin's Uprising]. Istoricheskij arhiv [Historical Archive], 1960, no. 6, pp. 119-142.

13. Podjapolskaya E.P., ed. Novye materialy o vosstanii na Donu i v Central'noj Rossii v 17071709 gg. [New Materials on the Uprising on the Don and in Central Russia in 1707-1709]. Materialy po istorii SSSR [Materials on the History of the USSR]. Moscow, 1957, iss. 5, pp. 503-564.

14. Lebedev V.I., ed. O podavlenii narodnogo vosstaniya 1707-1708 gg. [On the Suppression of the Popular Uprising of 1707-1708]. Istoricheskij arhiv [Historical Archive], 1955, no. 4, pp. 179-195.

15. Otpiska azovskogo gubernatora I.A. Tolstogo v Posol'skij prikaz. 8 dekabrya 1708 g. [The Report of the Azov Governor I.A. Tolstoy to the Ambassadorial Chancery. December 8, 1708]. RGADA, f. 159, op. 2, d. 5041, 1. 1-2ob.

16. Pavlenko N.I. K voprosu o roli donskogo kazachestva v krest'yanskih vojnah [On the Role of the Don Cossacks in Peasant Wars]. Social'noekonomicheskoe razvitie Rossii: sb. st. $k$ 100-letiyu so dnya rozhdeniya N.M. Druzhinina [Socio-Economic Development of Russia. Collection of Articles Dedicated to the $100^{\text {th }}$ Anniversary of N.M. Druzhinin]. Moscow, Nauka Publ., 1986, pp. 62-75.

17. Andreev A.I., ed. Pis'ma i bumagi imperatora Petra Velikogo [Letters and Papers of Emperor Peter the Great]. Moscow, Leningrad, Izd-voAN SSSR, 1946, vol. 7, iss. 2, VI, [639]-936 p.

18. Andreev A.I., ed. Pis'ma i bumagi imperatora Petra Velikogo [Letters and Papers of Emperor Peter the Great]. Moscow, Izd-vo AN SSSR, 1948, vol. 8, iss. $1.408 \mathrm{p}$.

19. Kafengauz B.B., ed. Pis'ma $i$ bumagi imperatora Petra Velikogo [Letters and Papers of Emperor Peter the Great]. Moscow, Izd-vo AN SSSR, 1951, vol. 8, iss. 2. 409-1180 p.

20. Kafengauz B.B., ed. Pis'ma $i$ bumagi imperatora Petra Velikogo [Letters and papers of Emperor Peter the Great]. Moscow, Leningrad, Izd-vo AN SSSR, 1950, vol. 9, iss. 1. 528 p.

21. Kafengauz B.B., ed. Pis'ma $i$ bumagi imperatora Petra Velikogo [Letters and Papers of Emperor Peter the Great]. Moscow, Izd-vo AN SSSR, 1952, vol. 9, iss. 2. 529-1622 p.

22. Podjapol'skaja E.P. Vosstanie Bulavina, 1707-1709 [The Bulavin Uprising 1707-1709]. Moscow, Izd-vo AN SSSR, 1962. 215 p.

23. Podjapol'skaja E.P. Krest'yanskaya vojna 1707-1709 gg. [Peasant War of the 1707-1709]. Smirnov I.I., Man'kov A.G., Podyapol'skaya E.P., Mavrodin V.V. Krest'yanskie vojny v Rossii XVII$X V I I I v v$. [Peasant Wars in Russia of the $17^{\text {th }}-$ $18^{\text {th }}$ Centuries]. Moscow, Leningrad, Nauka Publ., 1966, pp. 176-203.

24. Pronshtejn A.P., Mininkov N.A. Krest'yanskie vojny $v$ Rossii XVII-XVIII vekov $i$ donskoe kazachestvo [Peasant Wars in Russia of the $17^{\text {th }}-$ $18^{\text {th }}$ Centuries and the Don Cossacks]. Rostov-on-Don, Izd-vo Rostovskogo universiteta, $1983.420 \mathrm{p}$.

\section{Information About the Author}

Pyotr A. Avakov, Candidate of Sciences (History), Senior Researcher, Federal Research Centre The Southern Scientific Centre of the Russian Academy of Sciences, Chehov St, 41, 344006 Rostov-onDon, Russian Federation, pavakov@mail.ru, https://orcid.org/0000-0001-9051-5611

\section{Информация об авторе}

Петр Ашотович Аваков, кандидат исторических наук, старший научный сотрудник, Федеральный исследовательский центр Южный научный центр РАН, просп. Чехова, 41, 344006 г. Ростов-на-Дону, Российская Федерация, pavakov@mail.ru, https://orcid.org/0000-0001-9051-5611 